\title{
Host Crop Affects Rhizosphere Colonization and Competitiveness of 2,4-Diacetylphloroglucinol-Producing Pseudomonas fluorescens
}

\author{
Leonardo De La Fuente, Blanca B. Landa, and David M. Weller
}

First author: Department of Plant Pathology, Washington State University, Pullman 99164; second author: Departamento de Agronomía, Escuela Técnica Superior de Ingenieros Agrónomos y de Montes, Universidad de Córdoba, 14080 Córdoba, Spain; and third author: United States Department of Agriculture, Agricultural Research Service, Root Disease and Biological Control Research Unit, Pullman, WA 99164.

Accepted for publication 28 February 2006.

\begin{abstract}
De La Fuente, L., Landa, B. B., and Weller, D. M. 2006. Host crop affects rhizosphere colonization and competitiveness of 2,4-diacetylphloroglucinol-producing Pseudomonas fluorescens. Phytopathology 96:751762.

Strains of Pseudomonas fluorescens producing the antibiotic 2,4diacetylphloroglucinol (2,4-DAPG) are biocontrol agents which play a key role in the suppressiveness of some soils against soilborne pathogens. We evaluated the effect of the host plant genotype on rhizosphere colonization by both indigenous and introduced 2,4-DAPG-producing $P$. fluorescens. First, population densities of indigenous 2,4-DAPG producers in the rhizospheres of alfalfa, barley, bean, flax, lentil, lupine, oat, pea, and wheat grown in a Fusarium wilt-suppressive Puget silt loam were determined. Population densities differed among the various crops and among pea cultivars, with lentil and oat supporting the highest and lowest densities of 2,4-DAPG producers, respectively. Second, to determine the interactions among 2,4-DAPG producers in the rhizosphere, a Shano sandy loam was inoculated individually and with all possible combinations of P. fluorescens Q8r1-96 (genotype D), F113 (genotype K), and MVP1-4 (genotype P) and sown to wheat or pea, and the rhizosphere

densities, the outcome of the interactions differed according to the host crop. In the wheat rhizosphere, the population density of strain F113 was significantly greater than that of Q8r1-96 in the mixed inoculation studies, but no significant differences were observed on pea. The population density of strain Q8r1-96 was greater than that of MVP1-4 in the mixed inoculation on wheat, but the opposite occurred on pea. In the wheat rhizosphere, the population of MVP1-4 dropped below the detection limit $\left(\log 3.26 \mathrm{CFU} \mathrm{g}{ }^{-1}\right.$ of root) in the presence of F113; however, on pea, the population density of MVP1-4 was higher than that of F113. When all three strains were present together, F113 had the greatest density in the wheat rhizosphere, but MVP1-4 was dominant in the pea rhizosphere. Finally, eight pea cultivars were grown in soil inoculated with either MVP1-4 or Q8r1-96. The effect of the pea cultivar on rhizosphere colonization was dependent on the bacterial strain inoculated. Rhizosphere population densities of MVP1-4 did not differ significantly among pea cultivars, whereas population densities of Q8r1-96 did. We conclude from these studies that the host crop plays a key role in modulating both rhizosphere colonization by 2,4-DAPG-producing $P$. fluorescens and the interactions among different genotypes present in the same rhizosphere.
\end{abstract} population dynamics of each strain was monitored. All three strains were similar in ability to colonize the rhizosphere of wheat and pea when introduced alone into the soil; however, when introduced together in equal
Additional keywords: fluorescent pseudomonads, rhizosphere competitiveness, suppressive soils.
Strains of fluorescent Pseudomonas spp. have been studied extensively as biological control agents and many of the most effective strains produce one or more diffusible antibiotics, such as phenazine derivatives, pyoluteorin, pyrrolnitrin, oomycin A, viscosinamide, and 2,4-diacetylphloroglucinol (2,4-DAPG) (18, 47). 2,4-DAPG-producing Pseudomonas fluorescens strains are active against phytopathogenic bacteria, fungi, oomycetes, and nematodes $(10,11,13,18,23,31)$, and purified 2,4-DAPG has broad antiviral, antibacterial, antifungal, antihelminthic, and phytotoxic properties $(4,22,23)$. The mechanism of action of $2,4-\mathrm{DAPG}$ against phytopathogens is not fully elucidated, but it damages membranes and zoospores of Pythium spp. (14). The antibiotic also can protect plants indirectly by inducing resistance $(21,60)$.

The biosynthetic locus for 2,4-DAPG consists of six genes, phlF and phlACBDE (4), which are highly conserved among 2,4DAPG-producing isolates collected worldwide $(12,24,37,41,50)$. Particularly noteworthy is phlD, which encodes a polyketide

Corresponding author: D. M. Weller; E-mail address: wellerd@wsu.edu

DOI: 10.1094/PHYTO-96-0751

This article is in the public domain and not copyrightable. It may be freely reprinted with customary crediting of the source. The American Phytopathological Society, 2006 synthase with similarity to plant genes encoding chalcone or stilbene synthases (4). PhlD plays a key role in the two proposed routes for the biosynthesis of 2,4-DAPG: synthesis of phloroglucinol from glucose (1) and synthesis of the precursor monoacetylphloroglucinol (4). The term $\mathrm{phlD}^{+}$fluorescent Pseudomonas spp. and 2,4-DAPG producer are used synonymously because, among isolates tested from worldwide sources, detection of phlD correlates with the capacity to produce the antibiotic. phlD ${ }^{+}$isolates have been grouped into 22 genotypes (A to T, PfY, and $\mathrm{PfZ}$ ) on the basis of whole-cell repetitive sequence-based polymerase chain reaction (rep-PCR) analysis using the BOXA1R primer (BOX-PCR) $(28,29,41)$, restriction fragment length polymorphism (RFLP) analysis $(28,29,36,40)$, and phylogenetic analysis $(12,37)$ of phlD.

Despite extensive research, biocontrol agents account for only $1 \%$ of the agricultural chemical sales for plant health management in the United States (16), and only a handful of the biopesticides registered contain fluorescent Pseudomonas strains (16). One of the main impediments to the commercial use of biocontrol for soilborne pathogens is inconsistent performance, resulting in part from the impact of a wide variety of biotic and abiotic factors (host plant, soil type, and agricultural management practices, among others) on biocontrol activity (17) and plant colonization (58) by introduced bacteria and indigenous microorganisms (the 
main source of competitors for introduced agents). Factors that reduce colonization also can reduce biocontrol because a positive relationship often exists between root colonization by pseudomonads and disease suppression $(6,9)$; in addition, rhizobacteria must reach a threshold density in order to be effective $(46,48)$.

Many studies have documented the effect of plant species on microbial communities $(3,34,42,61)$ and on specific groups of bacteria $(5,30,32,38)$. Specific recognition between plants and symbiotic bacteria such as rhizobia is well documented $(7,55)$ but specialized relationships also seem to exist between certain nonsymbiotic biocontrol rhizobacteria and the host plant $(53,54)$. Thus, it is not surprising that plant species and cultivars differ in their response to rhizosphere colonization $(27,28,37,44)$ and disease suppression by introduced and indigenous rhizobacteria (35). For example, tomato recombinant inbred lines were used to show that three quantitative trait loci (QTL) were associated with disease suppression induced by Bacillus cereus UW85. One of these QTL was correlated with population growth of the bacteria on seed (54), implying that the host plant facilitates disease suppression by enhancing rhizobacterial growth. Smith and Goodman (54) suggested that identifying host genotypes supporting larger populations of biocontrol agents would help to improve disease suppression. Plants also initiate and maintain sophisticated mutualistic relationships with $p h l D^{+}$isolates (29), and certain $p h l D^{+}$ genotypes have an affinity or preference for the roots of certain crops at the species and cultivar level $(5,27-29,37,44)$. For example, indigenous populations of 2,4-DAPG producers are responsible in certain fields for the phenomenon known as take-all decline (TAD) $(15,48,59)$ : the spontaneous reduction in take-all disease (caused by Gaeumannomyces graminis var. tritici) severity after several years of barley or wheat monoculture $(19,59)$. Isolates of at least four genotypes $(\mathrm{B}, \mathrm{D}, \mathrm{E}$, and $\mathrm{L})$ occur in Washington State TAD fields $(41,49)$, but D-genotype isolates are most abundant (over $50 \%$ of the total), owing to the exceptional ability of isolates of this genotype to colonize wheat and barley $(27,49)$. In contrast, in Dutch TAD fields genotypes $M$ and $F$ are abundant $(15,41)$, but they appear to be absent in Washington TAD soils. Multiple genotypes of 2,4-DAPG producers also are found in fields of other crops (i.e., pea, flax, corn, and soybean) $(28,29,39)$; however, again one or two genotypes dominate depending on the geographical location $(15,41,49)$ and the host crop sown $(28,29,39)$. Nevertheless, little is known about the factors modulating the interactions among the genotypes of 2,4-DAPGproducing $P$. fluorescens present in a soil and the rhizosphere.

The objectives of this study were to evaluate the effect of host plant genotype on (i) rhizosphere colonization by indigenous and introduced 2,4-DAPG producing $P$. fluorescens and (ii) competition among strains of different BOX-PCR genotypes in the rhizosphere.

\section{MATERIALS AND METHODS}

Bacterial strains and growth media. P. fluorescens strains used in this study produced the antibiotic 2,4-DAPG: Pf-5 (genotype A) (20), Q2-87 (genotype B) (57), Q8r1-96 (genotype D) (48), MVP1-6 (genotype D) (28), F113 (genotype K) (51), 1M1-96 (genotype L) (49), MVP1-4 (genotype P) (28), and MVW1-1 (genotype P) (28). Spontaneous rifampicin-resistant mutants of $P$. fluorescens strains Q8r1-96, F113, and MVP1-4 were used in growth chamber studies $(27,28)$.

All strains were cultured at $28^{\circ} \mathrm{C}$ in one-third-strength King's medium B (1/3× KMB) broth or agar (26). Stock cultures were stored in $1 / 3 \times \mathrm{KMB}$ broth plus $20 \%$ glycerol at $-80^{\circ} \mathrm{C}$. When appropriate, antibiotics were added to media at the following concentrations: ampicillin (Amp), $40 \mu \mathrm{g} \mathrm{m}^{-1}$; chloramphenicol $(\mathrm{Cm})$, $13 \mu \mathrm{g} \mathrm{ml}^{-1}$; cycloheximide (Chex), $100 \mu \mathrm{g} \mathrm{ml}^{-1}$; and rifampicin (Rif), $100 \mu \mathrm{g} \mathrm{ml} \mathrm{m}^{-1}$. One-tenth-strength tryptic soy broth (TSB; Difco Laboratories, Detroit) supplemented with Chex (1/10x
$\mathrm{TSB}^{+}$) was used for quantification of total culturable heterotrophic bacteria.

Selection of indigenous 2,4-DAPG producers by crop species. A Puget silt loam was collected from the upper $30 \mathrm{~cm}$ of the soil profile from a field located at the Washington State University Research and Extension Center (Mount Vernon, WA), air dried, sieved, and stored at room temperature in plastic buckets. The field had been cropped continuously to pea for over 30 years, was suppressive to Fusarium wilt of pea caused by Fusarium oxysporum f. sp. pisi (28), and contained 2,4-DAPGproducing $P$. fluorescens genotypes A, D, L, O, P, and Q, which were detected when the soil was planted to pea or wheat (28). Soil $(200 \mathrm{~g})$ was added to pots ( 7 by 7 by $6.5 \mathrm{~cm}$ ) and planted to one of nine crops. For all legumes, 6 seed were sown per pot and, for the other crops, 10 seed were sown per pot: alfalfa (Medicago sativa L. cv. Magnum IV), barley (Hordeum vulgare L. cv. Baronesse), bean (Phaseolus vulgaris L. cv. Red Hoak), flax (Linum usitatissimum L. cv. Norlin), lentil (Lens culinaris Medik. cv. Brewer), lupine (Lupinus albus L. line 98LI8535), oat (Avena sativa L. cv. Caliber), pea (Pisum sativum L. cv. Columbian), and wheat (Triticum aestivum L. cv. Penawawa). Plants were grown in a growth chamber at $22 \pm 1{ }^{\circ} \mathrm{C}$, with a 12 -h photoperiod and 40 to $60 \%$ relative humidity. Soil in each pot was cropped to six successive cycles (see below) of the same plant species, with each cycle lasting 3 weeks, as previously described $(27,28)$. The cycling process was used because it allows root colonization studies to proceed in the greenhouse or growth chamber for weeks or months. Each treatment was replicated three times, with each pot serving as a replicate, and the experiment was arranged in a completely randomized design. Each pot was watered at the beginning of each cycle (see below) with $50 \mathrm{ml}$ of a suspension of metalaxyl (Syngenta, Greensboro, NC) at $2.5 \mathrm{mg} / \mathrm{ml}$ active ingredient to control Pythium root rot and damping-off. Pots were watered every 2 days with tap water, and once a week with $50 \mathrm{ml}$ of a $1 \times$ Miracle-Gro fertilizer solution (Scotts, Marysville, $\mathrm{OH}$ ).

At the end of each 3-week "cycle" of growth, plants were harvested and rhizosphere population densities of indigenous 2,4DAPG producers were determined (see below) on six randomly selected plants (two from each replicate pot). Shoots of the remaining plants of each crop were excised, and the soil and associated roots were decanted into a plastic bag and mixed by shaking. The soil was returned to the pots and sown again to begin the next cycle. Roots plus rhizosphere soils were assayed for indigenous 2,4-DAPG-producing Pseudomonas fluorescens isolates after each cycle, as previously described $(27,28)$. Populations of 2,4-DAPG producers were determined by using the PCR-based dilution-endpoint technique (40). This technique is based on the specific detection of phlD by PCR after serially diluted root washes are transferred to a selective growth medium. Briefly, the entire root system was excised from a seedling, and roots with associated rhizosphere soil were placed in 50-ml screw-cap centrifuge tubes containing $10 \mathrm{ml}$ of sterile water. The tube was agitated vigorously for $1 \mathrm{~min}$ on a Vortex mixer and then sonicated in an ultrasonic bath for $1 \mathrm{~min}$. Root washes were serially diluted (1:3) in sterile deionized water in 96-well microtiter plates and aliquots were transferred to wells of another plate containing 1/3× KMB supplemented with Chex, Cm, and Amp $\left(1 / 3 \times \mathrm{KMB}^{+++}\right)$, which is semi-selective for fluorescent pseudomonads. The plates were incubated for 48 to $72 \mathrm{~h}$ at room temperature $\left(22\right.$ to $\left.25^{\circ} \mathrm{C}\right)$ in the dark. The terminal dilution culture (TDC) was determined as the greatest dilution (well) showing bacterial growth (absorbance at $600 \mathrm{~nm}\left[\mathrm{OD}_{600 \mathrm{~nm}}\right] \geq 0.05$ ). Microtiter plates containing dilutions in $1 / 3 \times \mathrm{KMB}^{+++}$were frozen at $-20^{\circ} \mathrm{C}$ prior to analysis. Detection of phlD was conducted by PCR using the "generic" primers B2BF and BPR4 (40) designed for phlD-based detection of 2,4-DAPG producers. Wells of plates showing growth were analyzed starting from the TDC and continuing into lower dilutions until phlD-specific amplification 
products were detected in at least three consecutive wells. The population density was calculated based on the highest dilution with a phlD signal, as previously described $(12,27)$.

Rhizosphere colonization of wheat and pea by 2,4-DAPGproducing $\boldsymbol{P}$. fluorescens strains. A Shano sandy loam from a noncropped site near Quincy, WA (Quincy virgin soil) (28) was used to test the effect of crop species on the interactions among P. fluorescens strains Q8r1-96 (genotype D), F113 (genotype K), and MVP1-4 (genotype P). These strains were selected because of their superior ability to colonize the rhizosphere of wheat or pea (27-29). In a previous study (12), no inhibition occurred between these strains when grown together in broth culture, which allowed us to quantify the rhizosphere populations by a technique involving growth of both strains in the same culture. Bacteria were introduced into soil as a suspension in $1 \%$ methylcellulose (27) at $100 \mathrm{ml}$ of suspension per kilogram of soil. Single inoculation treatments consisted of $P$. fluorescens strains Q8r1-96, F113, and MVP1-4 individually introduced $\left(\approx 1 \times 10^{4} \mathrm{CFU} \mathrm{g}^{-1}\right.$ soil). Mixed treatments consisted of Q8r1-96 plus F113, Q8r1-96 plus MVP14 , and F113 plus MVP1-4, with each strain of a mixture introduced at $\approx 0.5 \times 10^{4} \mathrm{CFU} \mathrm{\textrm {g } ^ { - 1 }}$ soil); a triple mixture consisted of Q8r1-96, F113, and MVP1-4, each introduced at $\approx 0.33 \times$ $10^{4} \mathrm{CFU} \mathrm{g}^{-1}$ soil). Control soil received only a sterile $1 \%$ methylcellulose solution. Population densities of each introduced strain established in the soil (shown in "cycle 0") were determined by assaying three 0.5 -g samples from each inoculated soil by a modification of the PCR-based dilution endpoint assay (12) that used allele-specific PCR primers as described below. Soils were added to pots ( 7 by 7 by $6.5 \mathrm{~cm}, 200 \mathrm{~g} / \mathrm{pot}$ ) and either wheat (cv. Penawawa) or pea (cv. Columbian) was sown (six seed per pot) with seed pregerminated on moist paper at room temperature for 1 day. Pots were incubated in growth chambers at $15 \pm 1{ }^{\circ} \mathrm{C}$ (wheat) or $22 \pm 1{ }^{\circ} \mathrm{C}$ (pea), with a 12-h photoperiod and 40 to $60 \%$ relative humidity. Each pot was watered at the beginning of each cycle with $50 \mathrm{ml}$ of a suspension of metalaxyl as described above. Wheat was watered every other day and pea daily with tap water, and both crops received $50 \mathrm{ml}$ of a $1 \times$ Miracle-Gro fertilizer solution once a week. Soils were cycled with wheat or pea five times, with each cycle lasting 3 weeks. Each treatment was replicated three times with one pot serving as a replicate, and the experiment was arranged in a completely randomized design. The experiment was repeated three times with similar results. At the end of each cycle, roots with rhizosphere soil were excised from the plant and washed as described above.

Total culturable heterotrophic bacteria were quantified in $1 / 10 \times$ $\mathrm{TSB}^{+}$broth, as previously described (27). Population densities of each strain established in the soil ("cycle 0") and rhizosphere populations of introduced $P$. fluorescens strains were enumerated in $1 / 3 \times \mathrm{KMB}^{+++}$containing Rif $\left(\mathrm{KMB}^{++} \mathrm{Rif}\right)$ by using a modification (12) of the PCR-based dilution endpoint assay (40) described above that employs allele-specific PCR amplification of phlD, which allows the simultaneous detection of strains of different 2,4-DAPG genotypes in soil samples. All PCR reactions were carried out according to De La Fuente et al. (12). Primers D-gen-2 and B2BF were used for detection of strain Q8r1-96 (D-genotype), BPR4 and K-gen for F113 (K-genotype), and BPR4 and Pgen for MVP1-4 (P-genotype) (12). The TDC of all treatments were analyzed by allele-specific PCR with all three sets of primers. Additional PCR reactions were performed with samples from lower dilutions until an amplification product was detected in at least three consecutive samples.

Rhizosphere colonization of pea cultivars by 2,4-DAPGproducing indigenous populations and strains Q8r1-96 and MVP1-4. Two cycling experiments were carried out in the greenhouse as described above to assess the effect of pea cultivars on rhizosphere colonization by indigenous (experiment I) or introduced (experiment II) 2,4-DAPG-producing P. fluorescens. In experiment I, four pea cultivars, Columbian, Little Marvel,
Quincy, and WSU31, were sown (six seed per pot) in the Puget silt loam. In experiment II, Quincy virgin soil was inoculated with P. fluorescens Q8r1-96 (genotype D), MVP1-4 (genotype P) $(\approx 1 \times$ $10^{4} \mathrm{CFU} \mathrm{\textrm {g } ^ { - 1 }}$ soil each), or a sterile solution of methylcellulose (noninoculated control) and added (200 g) to pots, which were sown with the pea cvs. Alaska, Columbian, Joel, Little Marvel, Majorette, Quincy, Rex, and WSU31 (six seed per pot). In both experiments, pots were incubated in a growth chamber at $22 \pm$ $1{ }^{\circ} \mathrm{C}$, with a 12 -h photoperiod and 40 to $60 \%$ relative humidity. Each pot was watered at the beginning of each cycle with $50 \mathrm{ml}$ of a suspension of metalaxyl, daily with tap water, and once a week with $50 \mathrm{ml}$ of a $1 \times$ Miracle-Gro fertilizer solution. Each treatment was replicated three times, with one pot serving as a replicate, and the experiment was organized in a completely randomized design. Pea plants were grown for a total of two (experiment I) or four (experiment II) 3-week cycles and the roots plus rhizosphere soil were assayed for bacteria after each cycle as described above. Population sizes of indigenous (experiment I) and introduced (experiment II) bacteria were determined by the PCR-based dilution endpoint assay, using $1 / 3 \times \mathrm{KMB}^{+++}$(experiment I) or $1 / 3 \times \mathrm{KMB}^{++}$Rif (experiment II). For the detection of indigenous $p h l D^{+}$isolates in experiment I, PCR reactions were carried out with "generic" primers B2BF and BPR4. In experiment II, RFLP analysis of the phlD-amplified fragment was performed using the enzyme HaeIII $(28,36)$, which allows discrimination between Q8r1-96 (genotype D) and MVP1-4 (genotype P). When contamination with a noninoculated genotype was detected (experiment II), the allele-specific PCR technique (12) was used to determine the density of the subordinate strain as described above.

Growth kinetics in vitro at different incubation temperatures. Because the rhizosphere competitiveness assays on wheat and pea were performed in growth chambers set at different temperatures, we studied the effect of incubation temperature (15 and $22^{\circ} \mathrm{C}$ ) on the growth kinetics of P. fluorescens strains Pf-5, Q2-87, Q8r1-96, MVP1-6, F113, 1M1-96, MVP1-4, and MVW1-1, which are representatives of the most studied genotypes of 2,4DAPG producers. Overnight cultures of each strain in $1 / 3 \times \mathrm{KMB}$ broth were harvested by centrifugation in a microfuge $(10,000 \times$ $g, 5 \mathrm{~min}$ ) and suspended in the same media, and the concentration of the bacteria was adjusted to an $\mathrm{OD}_{600 \mathrm{~nm}}$ of 0.1 by using a SAFIRE microplate reader (Tecan Systems, Inc., San Jose, CA). Suspensions were diluted 1:10 with $1 / 3 \times$ KMB broth (approximate starting concentration $\left.1 \times 10^{7} \mathrm{CFU} \mathrm{ml}^{-1}\right)$ and added $(200 \mu \mathrm{l}$ per well) to 96 -well microtiter plates. Samples were replicated three times and the entire experiment was conducted twice. The plates were incubated at 15 and $22^{\circ} \mathrm{C}$ for $47 \mathrm{~h}$ and bacterial growth was monitored at 1-, 2-, or 6-h intervals with the SAFIRE microplate reader. Data from $\mathrm{OD}_{600 \mathrm{~nm}}$ values were converted to $\log$ CFU ml ${ }^{-1}$ by using the relationship $1 \mathrm{OD}_{600 \mathrm{~nm}}=1.53 \times 10^{9}$.

Data analysis. Population density data from greenhouse studies were converted to log CFU per gram of root fresh weight (without rhizosphere soil) to satisfy the assumptions of analysis of variance (ANOVA). For graphical representation of the data, the log of the arithmetic means was used because it best represents the actual mean population size. Differences in population densities among treatments were determined by standard ANOVA and mean comparisons among treatments were performed using Fisher's protected least significant difference (LSD) test at $P=0.05$ using the STATISTIX 8.0 software (Analytical Software, St. Paul, MN). Initial ANOVA analysis was performed as a factorial design (bacterial treatment, host crop, and cycle). Due to significant $(P<$ $0.05)$ interactions among these three factors, ANOVA was performed independently for each host crop, cycle, and specific bacterial treatment. Kruskal-Wallis analysis was performed whenever ANOVA assumptions were violated. Area under the colonization progress curve (AUCPC), previously used as a general measure of rhizosphere competence (28), was calculated by using the 
trapezoidal integration method (8). For rhizosphere samples in which no PCR signal for phlD was detected, population densities were set at the detection limit of the assay used, $\log 3.26 \mathrm{CFU} \mathrm{g}^{-1}$ of root for both the PCR-based dilution endpoint (40) and the allele-specific PCR technique (12).

\section{RESULTS}

Selection of indigenous populations of 2,4-DAPG-producing Pseudomonas isolates by different crops. 2,4-DAPG-producing fluorescent Pseudomonas isolates were detected in the rhizospheres of all crops (alfalfa, barley, bean, flax, lentil, lupine, oat, pea, and wheat) grown in the Puget silt loam, but population sizes differed significantly $(P<0.001)$ among crops (Fig. 1 ; Table 1$)$. In general, on the basis of AUCPC and population densities at each cycle, legumes (alfalfa, bean, lentil, lupine, and pea) supported the largest populations of 2,4-DAPG producers, followed by barley and wheat; flax and oat were significantly less supportive of 2,4-DAPG producers than the other crops (Fig. 1; Table $1)$. The AUCPC value for lentil was significantly $(P<0.001)$ greater than that for all of the other crops, whereas AUCPC values for flax and oat were significantly lower (Table 1). A population of $\log 5 \mathrm{CFU} \mathrm{g}^{-1}$ of root previously was shown to be the threshold density required for disease suppression in wheat (48), and crops differed significantly $(P<0.001)$ in the rate at which threshold densities developed in the rhizosphere. At the end of the first cycle of growth, densities of 2,4-DAPG producers on alfalfa, barley, flax, oat, and wheat were either at or below $\log 5 \mathrm{CFU} \mathrm{g}{ }^{-1}$ of root, whereas densities on bean, lentil, lupine, and pea were much greater: $\log 7.4,5.8,5.9$, and $6.4 \mathrm{CFU} \mathrm{\textrm {g } ^ { - 1 }}$ of root, respectively. After the second cycle, only oat did not consistently support population densities above the threshold (Fig. 1). The crops also varied in the frequency of individual root samples in which 2,4-DAPG producers were above the detection limit of log $3.26 \mathrm{CFU} \mathrm{g} \mathrm{g}^{-1}$ of root. Across all six cycles, the percentage of individual root samples ( $n=36$ for each crop) of alfalfa, barley, bean, flax, lentil, lupine, oat, pea, and wheat in which $p h l D^{+}$ isolates were above the detection limit was $83,92,94,64,92,86$, 61,97 , and $86 \%$, respectively (Table 1 ).

Growth in vitro of 2,4-DAPG producers at 15 and $22^{\circ} \mathrm{C}$. Growth kinetics in $1 / 3 \times \mathrm{KMB}$ were determined in order to eliminate a possible effect of incubation temperature on the relative growth of $P$. fluorescens strains Q8r1-96, F113, and MVP1-4. Relative growth of eight $P$. fluorescens strains, including Q8r1-96, F113, and MVP1-4 did not differ at incubation temperatures of $15^{\circ} \mathrm{C}$ (Fig. 2A) or $22^{\circ} \mathrm{C}$ (Fig. 2B). All strains grew faster at $22^{\circ} \mathrm{C}$. At both temperatures, the slowest-growing strain was Q2-87 and the fastest was Pf-5. Similar results were obtained when the experiment was repeated. These results allowed us to use incubation temperatures in our competition assays that are ideal for wheat and pea.

Competitiveness of $P$. fluorescens Q8r1-96 (genotype D), F113 (genotype K), and MVP1-4 (genotype P) in the rhizosphere of wheat and pea. Wheat and pea were used to assess

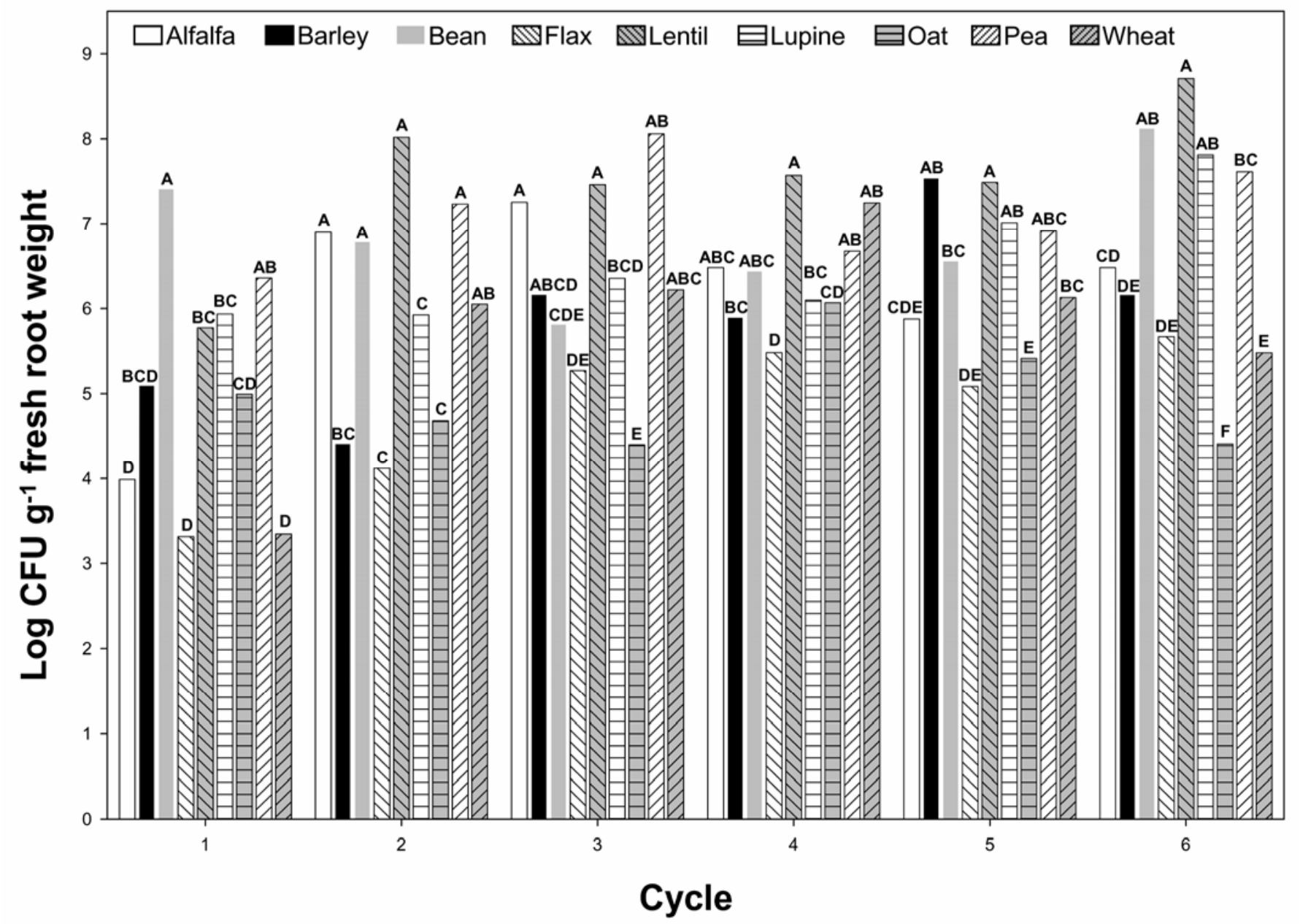

Fig. 1. Population densities of indigenous 2,4-diacetylphloroglucinol-producing fluorescent Pseudomonas spp. in the rhizospheres of alfalfa, barley, bean, flax, lentil, lupine, oat, pea, and wheat grown in a Fusarium wilt-suppressive soil (Puget silt loam) for six successive cycles of 3 weeks each. Population densities of phlD $D^{+}$fluorescent Pseudomonas spp. were enumerated after each cycle and log transformed before data analysis. Populations are expressed as log of the mean $\mathrm{CFU} \mathrm{g}{ }^{-1}$ of root (fresh weight after washing). Bars in the same cycle with the same letter are not significantly different $(P=0.05)$ according to Fisher's protected least significant difference test. 
whether the host crop modulates interactions among 2,4-DAPGproducing strains in the rhizosphere. Competition among $P$. fluorescens Q8r1-96 (genotype D), F113 (genotype K), and MVP1-4 (genotype P) was affected by the host crop. When strains Q8r1-96 (genotype D) and F113 (genotype K) were introduced separately into soil that then was planted either to wheat or pea, the population densities of the two strains in the wheat rhizosphere did not differ significantly $(P=0.425)$ in any of the five cycles (Fig. 3A, solid bars). In the pea rhizosphere, the density of Q8r1-96 was significantly greater $(P=0.049)$ than that of F113 only in cycle 3 (Fig. 3B, solid bars). However, AUCPC values (Table 2) showed that F113 colonized wheat better than Q8r1-96 when introduced individually, and that both strains colonized pea equally well. When strains Q8r1-96 and F113 (Fig. 3A, dashed bars) were present together in the wheat rhizosphere, the population size of F113 was significantly greater than that of Q8r1-96 in the third, fourth, and fifth cycles $(P<0.001, P<0.001$, and $P=0.010$, respectively), indicating that F113 was more competitive. However, when introduced together into the pea rhizosphere, the densities of the two strains did not differ significantly $(P=0.464)$ in any cycle (Fig. 3B, dashed bars), indicating that the strains were equally competitive on pea. AUCPC values confirmed these results. The AUCPC value for F113 in mixed inoculations (Q8r1$96+$ F113 $)$ on wheat was significantly $(P<0.001)$ higher than that for Q8r1-96, but the values for the two strains on pea did not differ (Table 2).

When strains Q8r1-96 (genotype D) and MVP1-4 (genotype P) were introduced separately into soil, population densities of the two strains did not differ significantly $(P=0.840)$ in the wheat rhizosphere during any of the cycles (Fig. 3C, solid bars). However, MVP1-4 colonized the pea rhizosphere significantly $(P<$ 0.001) better than Q8r1-96 during the last two cycles (Fig. 3D, solid bars). The AUCPC for Q8r1-96 was greater than that of MVP1-4 on wheat and the opposite occurred on pea (Table 2) when the strains were introduced individually. When strains Q8r1-96 and MVP1-4 were present together in the wheat rhizosphere, the population size of Q8r1-96 was significantly $(P<$ 0.001) greater than that of MVP1-4 (Fig. 3C, dashed bars) in cycles 1, 2, 3, and 4, indicating that Q8r1-96 outcompeted MVP14. Differences between the population sizes of the two strains were as great as $\log 3 \mathrm{CFU} \mathrm{g}^{-1}$ of root in cycle 3 . However, when the two strains were present together in the pea rhizosphere, the

TABLE 1. Selection of indigenous populations of 2,4-diacetylphloroglucinol (2,4-DAPG)-producing fluorescent Pseudomonas spp. by different crop species grown in a Puget silt loam ${ }^{\mathrm{w}}$

\begin{tabular}{llc}
\hline Host crop & AUCPC & $\begin{array}{c}\text { Root samples with } p^{\mathrm{x}} \\
\text { isolates }(\%)^{\mathrm{z}}\end{array}$ \\
\hline Alfalfa & $30.31 \mathrm{bcd}$ & 83 \\
Barley & $27.06 \mathrm{e}$ & 92 \\
Bean & $31.14 \mathrm{bc}$ & 94 \\
Flax & $22.25 \mathrm{f}$ & 64 \\
Lentil & $35.51 \mathrm{a}$ & 92 \\
Lupine & $28.81 \mathrm{cde}$ & 86 \\
Oat & $21.55 \mathrm{f}$ & 61 \\
Pea & $32.58 \mathrm{~b}$ & 97 \\
Wheat & $28.01 \mathrm{de}$ & 86 \\
\hline
\end{tabular}

${ }^{\text {w}}$ Table provides a summary of the data shown in Figure 1. Means in the same column followed by the same letter are not significantly different $(P=0.05)$ according to Fisher's protected least significant difference test.

${ }^{x}$ Seed were sown in a Puget silt loam from Mt. Vernon, WA that has been cropped to pea for over 30 years and is suppressive to Fusarium wilt of pea. Plants were grown in a growth chamber and populations of 2,4-DAPG producers were assayed during six consecutive 3 -week cycles.

y The area under the colonization progress curve (AUCPC) provides a general measure of root colonization across all growth cycles and was calculated by using the trapezoidal integration method (8).

${ }^{\mathrm{z}}$ Percentage of root systems from individual seedlings with population densities of 2,4-DAPG producers above the limit of detection (3.26 CFU g ${ }^{-1}$ of root); $n=36$ samples for each crop across all six growth cycles. opposite occurred, and MVP1-4 out-competed Q8r1-96; the population size of MVP1-4 was significantly greater than that of Q8r1-96 in cycles 3, 4, and $5(P<0.001)$ (Fig. 3D, dashed bars). The AUCPC value for MVP1-4 in the mixed inoculation (Q8r1$96+$ MVP1-4) was significantly greater $(P<0.001)$ than the value for Q8r1-96 on pea, but the opposite was observed on wheat (Table 2).

When strains F113 (genotype K) and MVP1-4 (genotype P) were introduced separately into soil, only small differences in population densities of the two strains occurred in the wheat and pea rhizospheres. In the wheat rhizosphere, the population size of F113 was significantly $(P<0.001)$ greater than that of MVP1-4 in cycles 1 and 2 (Fig. 3E, solid bars); however, in the pea rhizosphere, MVP1-4 was significantly $(P<0.001)$ greater than F113 in cycle 5 (Fig. 3F, solid bars). The AUCPC value for F113 was greater than that of MVP1-4 in the wheat rhizosphere, but the opposite occurred in the pea rhizosphere (Table 2). When F113 and MVP1-4 were introduced into the soil together, F113 strongly outcompeted MVP1-4 in the wheat rhizosphere (Fig. 3E, dashed bars). The population density of MVP1-4 declined steadily, was significantly $(P<0.001)$ lower than the density of F113 in all five cycles, and dropped below the detection limit $\left(\log 3.26 \mathrm{CFU} \mathrm{g}{ }^{-1}\right.$ root) during cycle 5 . In contrast, in the pea rhizosphere, the population sizes of the two strains were equivalent except in cycles 2 and 5, when the density of MVP1-4 was significantly $(P=0.010$ and $P<0.001$, respectively) greater than that of F113 (Fig. 3F, dashed bars). The AUCPC value for F113 in the mixed inoculation (F113+MVP1-4) was significantly higher $(P<0.001)$ than

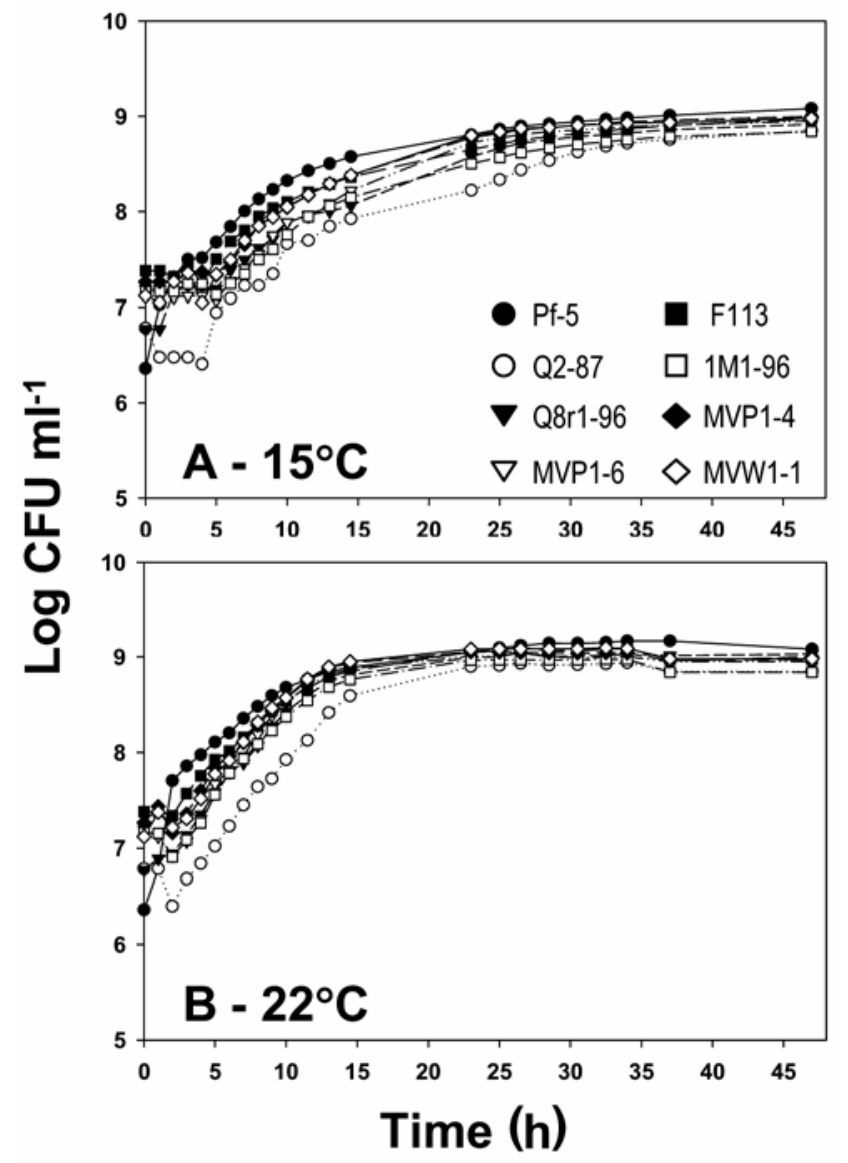

Fig. 2. Growth kinetics of phlD ${ }^{+}$Pseudomonas fluorescens strains in vitro at different incubation temperatures. P. fluorescens strains Pf-5, Q2-87, Q8r1-96, MVP1-6, F113, 1M1-96, MVP1-4, and MVW1-1 were grown in one-thirdstrength King's medium B broth. Cultures were incubated at $\mathbf{A}, 15^{\circ} \mathrm{C}$ and $\mathbf{B}$, $22^{\circ} \mathrm{C}$ and bacterial growth was measured at absorbance at $600 \mathrm{~nm}$ for $47 \mathrm{~h}$. The experiment was repeated twice, and means from a representative experiment are shown. 
Wheat
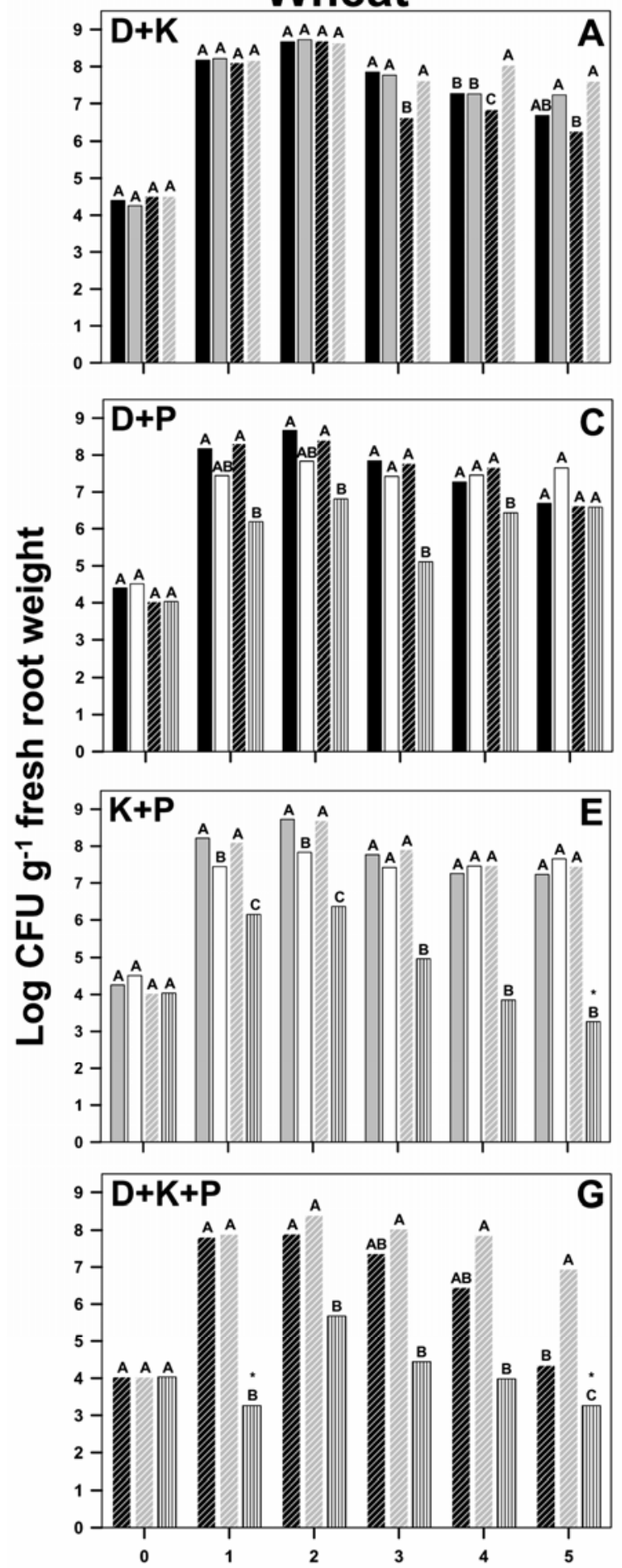

Pea
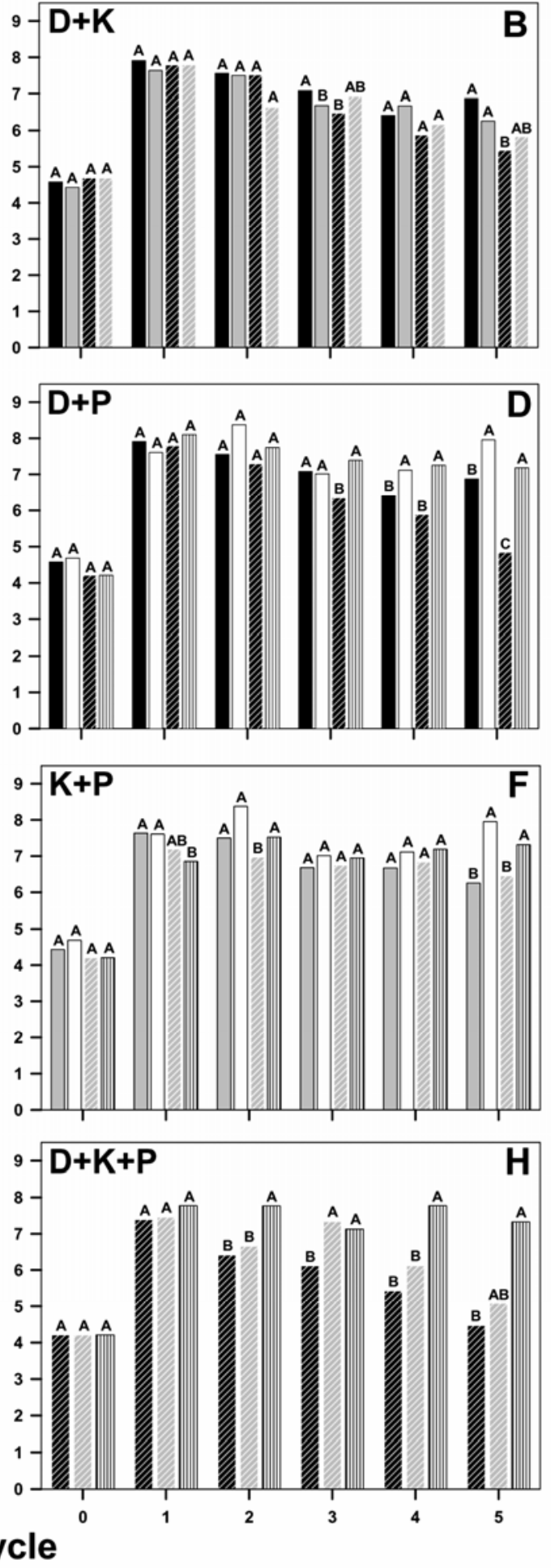

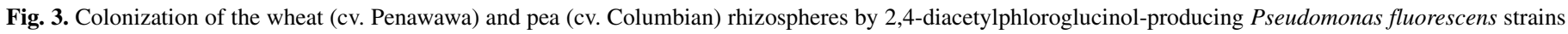

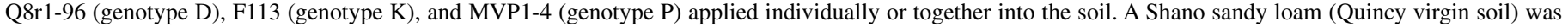

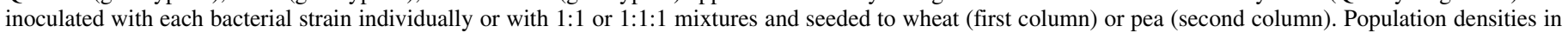

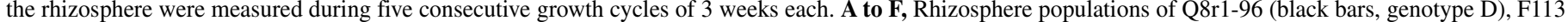

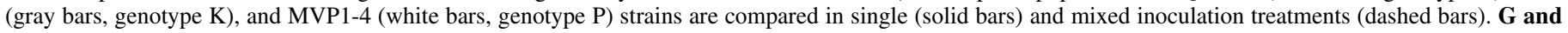

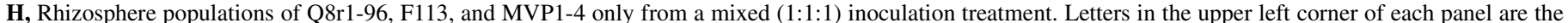

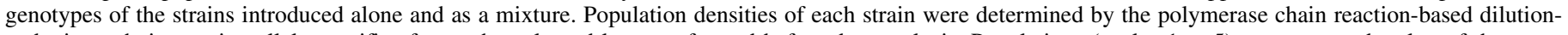

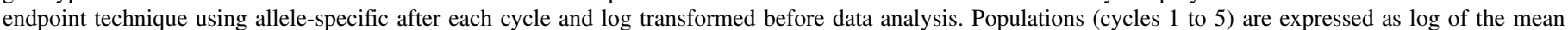

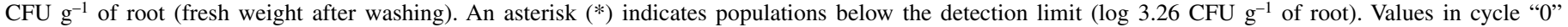

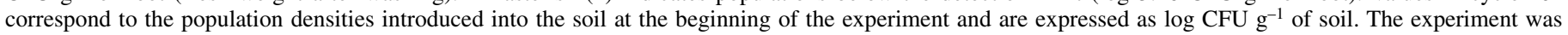

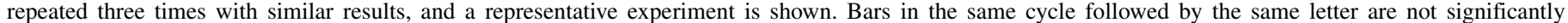

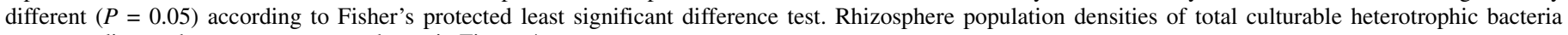
corresponding to these treatments are shown in Figure 4. 
that of MVP1-4 on wheat, but the opposite was observed on pea (Table 2).

When strains Q8r1-96 (genotype D), F113 (genotype K) and MVP1-4 (genotype P) were mixed together into the soil, F113 strongly outcompeted MVP1-4 and Q8r1-96 (Fig. 3G) in the wheat rhizosphere. The density of F113 was 1,000-fold greater than that of Q8r1-96 in cycle 5, and the population size of MVP14 dropped below the detection limit in cycles 1 and 5. The population densities of the three strains in the pea rhizosphere were substantially different from those in the wheat rhizosphere (Fig. $3 \mathrm{H})$. In the pea rhizosphere, the population density of MVP1-4 was significantly $(P<0.001)$ greater than that of Q8r1-96 in cycles 2 through 5 and significantly greater than that of F113 in cycles 2 and 4 . The population density of strains Q8r1-96 and F113 declined from cycle 3 to 5 (Fig. 3H). The AUCPC value for MVP1-4 was the lowest of the three strains in the wheat rhizosphere, but the value for MVP1-4 was the highest in the pea rhizosphere, whereas values for Q8r1-96 and F113 did not differ significantly $(P=0.502$ and 0.260 for wheat and pea, respectively) on either crop (Table 2).

The population densities of total culturable aerobic heterotrophic bacteria did not differ significantly among the treatments described above in either the wheat or pea rhizosphere $(P=0.845$ and 0.482 for wheat and pea, respectively) (Fig. 4); in addition, densities of total bacteria in the wheat and pea rhizospheres also were the same (Fig. 4A and B).

Effect of pea cultivar on rhizosphere colonization. Population densities of indigenous fluorescent Pseudomonas spp. and 2,4-DAPG producers differed significantly $(P=0.003)$ among the four pea cultivars (Fig. 5) grown in Puget silt loam. In both of two cycles, 'Little Marvel' supported the highest populations of both total fluorescent pseudomonads (Fig. 5A) and 2,4-DAPG-producing Pseudomonas spp. (Fig. 5B). Cultivars WSU31 and Columbian supported intermediate populations and Quincy supported the lowest populations of 2,4-DAPG-producers (Fig. 5B).

To further assess the effect of pea cultivar on rhizosphere colonization, strains Q8r1-96 (genotype D) and MVP1-4 (genotype $\mathrm{P}$ ) were introduced separately into the Shano sandy loam and eight pea cultivars then were grown in the soils for four cycles. Significant differences in the population density of Q8r1-96 in the rhizosphere of the eight pea cultivars occurred (Fig. 6A); however, those differences were not consistent across all four cycles. For example, the population densities of Q8r1-96 on 'Little Marvel' and 'Alaska' differed by $\log 2.3$ and $1.6 \mathrm{CFU} \mathrm{g}{ }^{-1}$ root in cycles 1 and 2, respectively, but no differences were detected in cycles 3 and 4 (Fig. 6A). In contrast, strain MVP1-4 colonized the rhizosphere of all cultivars in all cycles to the same extent (Fig. 6B).
An unexpected contamination by MVP1-4 of soils inoculated originally with Q8r1-96 and seeded with the pea cvs. Alaska, Joel, Majorette, and WSU31 was observed in the fourth cycle (Fig. 6A). Strain MVP1-4 was detected in the TDC as the most abundant strain in the rhizosphere of those four cultivars, indicating that contamination had occurred. An analysis using allele-specific PCR showed that the density of Q8r1-96 dropped $\approx \log 1 \mathrm{CFU} \mathrm{g}$ of root below the density of MVP1-4. The results of this unexpected contamination are consistent with our observations from the co-inoculation study (Fig. 3), showing that strain MVP1-4 outcompetes Q8r1-96 in the pea rhizosphere.

\section{DISCUSSION}

In this study, we focused on the effect of the host crop on rhizosphere colonization by 2,4-DAPG-producing fluorescent pseudomonads. First, we determined the ability of nine crops to support indigenous populations of 2,4-DAPG producers, which generally survive in bulk soil at densities below the detection level, but rapidly proliferate in the rhizosphere when a crop is grown. Pea monoculture over a span of 30 years in a field at Mount Vernon, WA, has enriched populations of 2,4-DAPG producers that rapidly respond to plant roots. Thus, the Puget silt loam from that field was an ideal medium to compare the supportiveness of different crop rhizospheres to these bacteria. The nine crops differed in the size of the populations of 2,4-DAPG producers supported over time and the rate at which threshold densities $\left(\log 5 \mathrm{CFU} \mathrm{g}{ }^{-1}\right.$ of root) were reached. All legumes (alfalfa, bean, lentil, lupine, and pea) and wheat and barley supported larger populations of phlD ${ }^{+}$isolates during the cycling experiments than did oat and flax, as measured by AUCPC values (Fig. 1; Table 1). Flax and oat also had the lowest frequency of $p h l D^{+}$isolates detected in individual root samples $(\approx 60 \%)$ (Table 1$)$. The lower supportiveness of the oat rhizosphere to 2,4-DAPG producers previously was observed (48). Bergsma-Vlami et al. (5) reported that lily was the least supportive of $p h l D^{+}$strains of four crops tested in Dutch soils. Of interest is the fact that both oat and species of Liliaceae are known for producing steroid saponines. The saponines avenacoside A and B (33), produced by oat in the rhizosphere, have broad-spectrum antimicrobial activity and may be a factor in the low supportiveness of oat to 2,4-DAPG producers.

Recent studies have demonstrated conclusively that the plant species modulates the population size and composition of indigenous or introduced 2,4-DAPG producers $(5,29,39,45)$. However, little information is available on whether the host plant affects competition among genotypes of 2,4-DAPG producers in the rhizosphere. This is an important question because multiple BOXPCR genotypes of 2,4-DAPG producers commonly occur in a

TABLE 2. Colonization of the wheat and pea rhizospheres by Pseudomonas fluorescens strains Q8r1-96, F113, and MVP1-4 applied individually or together into the soil ${ }^{\mathrm{X}}$

\begin{tabular}{|c|c|c|c|c|c|c|}
\hline \multirow[b]{3}{*}{ Treatment $^{\mathrm{y}}$} & \multicolumn{6}{|c|}{$\mathrm{AUCPC}^{\mathrm{z}}$} \\
\hline & \multicolumn{3}{|c|}{ Wheat } & \multicolumn{3}{|c|}{ Pea } \\
\hline & Q8r1-96 & F113 & MVP1-4 & Q8r1-96 & F113 & MVP1-4 \\
\hline F113 & $\ldots$ & $30.21 \mathrm{a}$ & $\ldots$ & $\ldots$ & $22.69 \mathrm{bc}$ & \\
\hline MVP1-4 & $\ldots$ & & $25.98 \mathrm{e}$ & $\ldots$ & & $25.47 \mathrm{a}$ \\
\hline Q8r1-96 + F113 & $27.41 \mathrm{bcd}$ & $29.76 \mathrm{a}$ & $\ldots$ & $21.66 \mathrm{c}$ & $22.50 \mathrm{bc}$ & $\ldots$ \\
\hline Q8r1-96 + MVP1-4 & $27.97 \mathrm{bc}$ & & $26.38 \mathrm{de}$ & $18.63 \mathrm{de}$ & & $25.14 \mathrm{a}$ \\
\hline
\end{tabular}

${ }^{x}$ Table provides a summary of the data shown in Figure 3. Means corresponding to the same crop and followed by the same letter are not significantly different $(P=0.05)$ according to Fisher's protected least significant difference test.

${ }^{y}$ A Shano sandy loam was inoculated with P. fluorescens Q8r1-96, F113, or MVP1-4 alone or with mixtures of these strains, planted to wheat (cv. Penawawa) or pea (cv. Columbian) and incubated in the growth chamber at 15 and $22^{\circ} \mathrm{C}$, respectively.

${ }^{\mathrm{z}}$ The area under the colonization progress curve (AUCPC) provides a general measure of root colonization across all growth cycles and was calculated by using the trapezoidal integration method (8). 
field, yet only one or two genotypes may dominate in the rhizosphere of a certain crop, especially in disease-suppressive soils $(15,28,29,39)$. Using the allele-specific primers, we were able to address the question of competition among genotypes in the wheat and pea rhizospheres. We showed for the first time that the host crop plays a key role in the competition among genotypes of 2,4-DAPG producers (Fig. 3; Table 2). The three strains used in this study were selected because they are known to be highly effective colonists of the wheat or pea rhizospheres (27-29). When inoculated separately, all three strains aggressively colonized the wheat and pea rhizospheres, but they were not identical in their colonization of these two crops (Fig. 3). The AUCPC values showed that F113 (genotype K) was slightly more aggressive on wheat than Q8r1-96 (genotype D) and MVP1-4 (genotype P), and that MVP1-4 was slightly more aggressive on pea than the other two strains (Table 2). However, when the strains were introduced

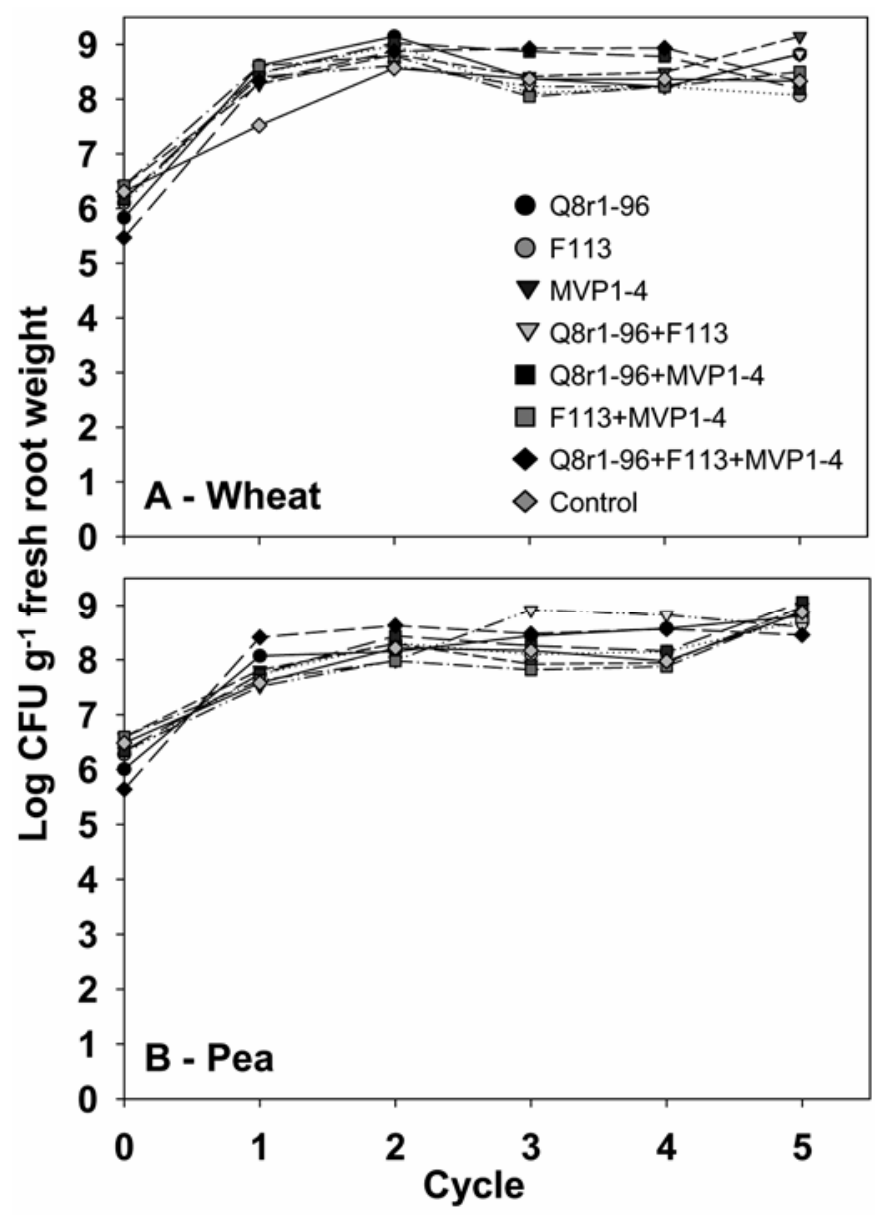

Fig. 4. Population densities of total culturable aerobic heterotrophic bacteria in the rhizospheres of wheat (cv. Penawawa) and pea (cv. Columbian) grown in a Shano sandy loam. Samples were from the study of the rhizosphere colonization of wheat and pea by Q8r1-96 (genotype D), F113 (genotype K), and MVP1-4 (genotype P). Total bacterial populations in the samples were determined by the dilution-endpoint assay using one-tenth-strength tryptic soy broth supplemented with cycloheximide after each cycle and log transformed before data analysis. Populations (cycles 1 to 5) are expressed as log of the mean CFU $\mathrm{g}^{-1}$ of root (fresh weight after washing). Treatments included Shano sandy loam inoculated with Pseudomonas fluorescens strains Q8r1-96, F113, MVP1-4, Q8r1-96 + F113, Q8r1-96 + MVP1-4, F113 + MVP1-4, Q8r1$96+$ F113 + MVP1-4, or methylcellulose (noninoculated control). Inoculated soils were then sown to $\mathbf{A}$, wheat or $\mathbf{B}$, pea for five consecutive cycles of 3 weeks each. Values in cycle " 0 " correspond to the total bacterial population in the soil at the beginning of the experiment after strains Q8r1-96, F113, and MVP1-4 were introduced and are expressed as $\log \mathrm{CFU} \mathrm{g}^{-1}$ of soil. The experiment was repeated three times with similar results, and a representative experiment is shown. Population density data of the corresponding inoculated phlD ${ }^{+}$strains are shown in Figure 3. together, the host plant showed a very strong influence on competition among strains (Fig. 3). In the wheat rhizosphere, F113 outcompeted Q8r1-96 (Fig. 3), consistent with the findings of Landa et al. (27), but F113 was not more competitive than Q8r196 in the pea rhizosphere. The most striking effect of the plant host on intergenotype competition occurred with MVP1-4. When applied alone, strain MVP1-4 aggressively colonized wheat; however, when placed in competition with F113 or Q8r1-96, it became a very poor colonizer and, in some cycles, its density even dropped below the detection limit (Fig. 3). In striking contrast in co-inoculation studies, strain MVP1-4 outcompeted strains Q8r196 and F113 in the pea rhizosphere (Fig. 3; Table 2). The competitiveness of the $\mathrm{P}$ genotype against other genotypes in the pea rhizosphere is further supported by the study of Landa et al. (28), which showed that strain MVP1-4 (genotype P) displaced strain MVW4-2 (genotype Q) when MVP1-4 contaminated soil originally inoculated with MVW4-2. Similarly, in our study, MVP1-4 displaced Q8r1-96 in the rhizospheres of pea cvs. Alaska, Joel, Majorette, and WSU31 after four cycles, in soils originally inoculated only with Q8r1-96 (Fig. 6). The possible route of this type of contamination was discussed previously (28). Collectively, these findings are especially interesting because Q8r1-96, F113, and MVP1-4 are strains of $P$. fluorescens quite similar phenotypically and produce similar amounts of $2,4-$ DAPG $(36,41,59)$.

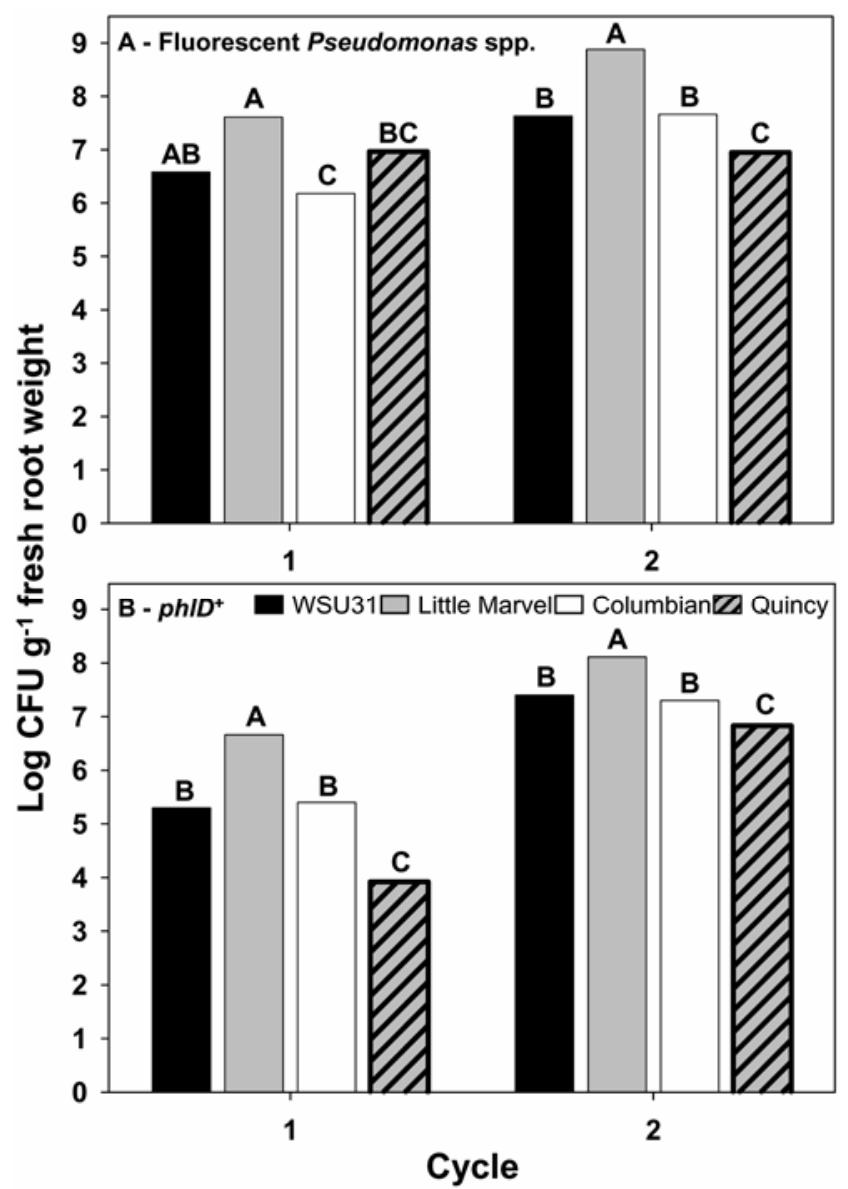

Fig. 5. Populations densities of indigenous fluorescent Pseudomonas spp. and 2,4-diacetylphloroglucinol-producing fluorescent Pseudomonas spp. in the rhizosphere of four pea cultivars grown in a Puget silt loam: WSU31, Little Marvel, Columbian, and Quincy. Plants were grown in a growth chamber at $22^{\circ} \mathrm{C}$ for two successive cycles of 3 weeks each. The population densities of A, fluorescent Pseudomonas spp. and B, phlD ${ }^{+}$fluorescent Pseudomonas spp. were enumerated after each cycle and $\log$ transformed before data analysis. Populations are expressed as $\log$ of the mean $\mathrm{CFU} \mathrm{g} \mathrm{g}^{-1}$ of root (fresh weight after washing). Bars in the same cycle with the same letter are not significantly different $(P=0.05)$ according to Fisher's protected least significant difference test. 
Two key unanswered questions are why one BOX-PCR genotype outcompetes another genotype on a certain host, and what mechanism is involved. One possibility is that the niche overlap in the rhizosphere environment results in direct antagonism of one strain by another (29). Landa et al. (27) used a de Wit replacement series to demonstrate an antagonism of P. fluorescens Q2-87 (genotype B) by Q8r1-96 (genotype D) in the wheat rhizosphere. Validov et al. (56) screened a collection of 2,4-DAPG-producing $P$. fluorescens and showed that over $70 \%$ of the isolates had antagonistic activity against other isolates in vitro and, in some cases, this activity was explained by the production of bacterio- cins (56). However, additional studies showed that Q8r1-96, F113, and MVP1-4 were not antagonistic in vitro against each other upon induction of bacteriocin production (S. Validov, D. V. Mavrodi, D. M. Weller, and L. S. Thomashow, unpublished data). Nevertheless, differential expression of antagonistic factors by the genotypes in the pea and wheat rhizospheres cannot be ruled out. A second possibility is that the composition and amount of root exudates (29), or the physical or chemical composition of the rhizosphere environment of a particular host, favors the growth of one genotype over another. Although this explanation is appealing given that the quantity and composition of the rhizodeposition

口WSU31 $\square$ Little Marvel $\square$ Columbian $\boldsymbol{Z}$ Quincy $\mathbb{Z}$ Rex $\boxminus$ Alaska $\boxminus$ Majorette $\square$ Joel

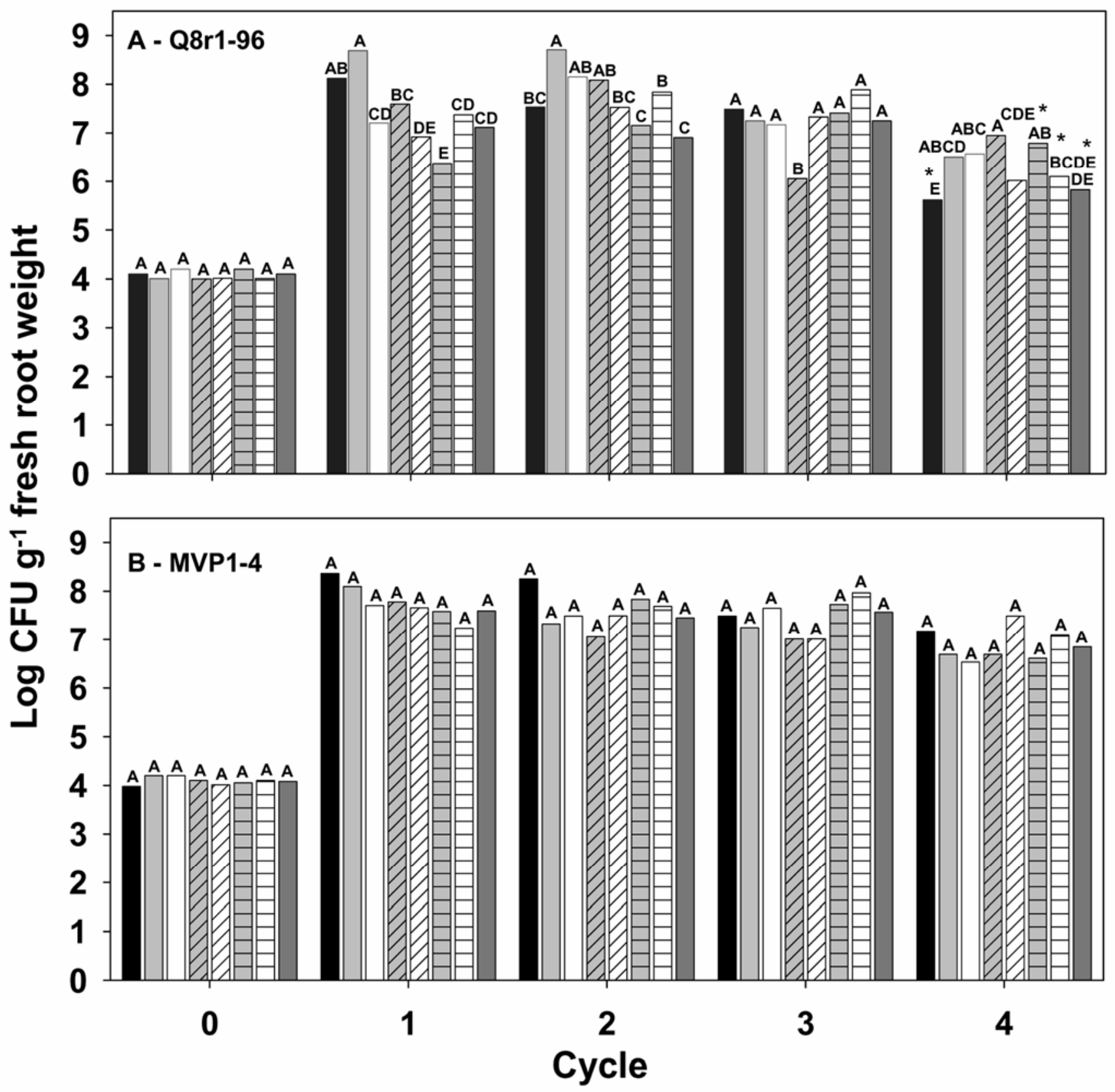

Fig. 6. Rhizosphere colonization of pea cultivars by Pseudomonas fluorescens Q8r1-96 (genotype D) and MVP1-4 (genotype P). A Shano sandy loam (Quincy virgin soil) was inoculated with either A, P. fluorescens Q8r1-96 or B, MVP1-4 and seeded with eight pea cultivars: WSU31, Little Marvel, Columbian, Quincy, Rex, Alaska, Majorette, and Joel. Plants were grown in a growth chamber at $22^{\circ} \mathrm{C}$ for four successive cycles of 3 weeks each. The population density of each introduced $p h l D^{+}$strain was enumerated after each cycle and log transformed before data analysis. Populations (cycles 1 to 4 ) are expressed as log of the mean CFU $\mathrm{g}^{-1}$ of root (fresh weight after washing) Values at cycle "0" correspond to population densities of Q8r1-96 and MVP1-4 established in the soil at the beginning of the experiment and are expressed as $\log \mathrm{CFU} \mathrm{g} \mathrm{g}^{-1}$ of soil. Bars in the same cycle with the same letter are not significantly different $(P=0.05)$ according to Fisher's protected least significant difference test. An asterisk (*) indicates treatments that became contaminated with MVP1-4. 
and the root architecture is under the genetic control of the plant (29), it again must be stressed that different genotypes defined by BOX-PCR differ little in their carbon utilization profiles $(41,49)$. However, classical carbon and nitrogen utilization profiles probably do not reflect the full range of organic substrates in rhizodeposition that the rhizobacteria encounter. Studies conducted to date show no significant differences among genotypes in growth on seed and root exudates of wheat and pea (L. De La Fuente and D. M. Weller, unpublished data). A third possibility is that some genotypes have an affinity or preference for the roots of a particular crop, due to unknown rhizobacterial traits that allow certain genotypes to more aggressively colonize the roots of the host plant because of more efficient attachment to the root, transport with the growing root, occupation of favored sites, or survival in senescent root tissue (29). Finally, an effect of other unknown microorganisms on the interaction between the roots and strains of $P$. fluorescens cannot be discarded.

The positive relationship between root colonization and biocontrol activity by introduced or indigenous rhizobacteria is well established $(9,46,48,49)$. The activity of the total culturable heterotrophic rhizosphere microflora is considered a major biotic factor that can affect the colonization and biocontrol activity of rhizobacteria (58). However, our results suggest that the total culturable bacteria may only play a minimal role in the differential competitiveness of strains Q8r1-96, F113, and MVP1-4 in the pea and wheat rhizosphere because the population size of the total bacterial population did not differ among treatments and crops (Fig. 4). Our results further suggest that, in biocontrol studies, the failure of introduced rhizobacteria to establish and persist in the rhizosphere may result more from very specific competition from indigenous, closely related strains with the same biocontrol traits and overlapping niches, than from general competition with the total microflora. This scenario could explain the variability in colonization and disease suppression that often occurs when rhizobacteria are applied to soils with different microbial communities (58). Our results also have implications for the application of strain mixtures, which is thought to be an effective method to enhance biocontrol activity $(43,52)$. Closely related strains sharing the same traits and niches may need to be avoided because competition in the rhizosphere is likely to result in the displacement of less competitive strains and compromise their potential to add to the activity of the mixture.

Finally, we tested the effect of the pea cultivar on rhizosphere colonization by indigenous and introduced 2,4-DAPG producers. Previous studies have documented differential responses of plant cultivars to beneficial microorganisms. For example, cultivars of potato (3), maize, and grass (Poa pretense) (42) that differed in their susceptibility to soilborne pathogens also differed quantitatively and qualitatively in their rhizosphere microflora. In addition, the ability of crop monoculture to render soils suppressive to pathogens is affected by the cultivar planted, as was shown for certain watermelon cultivars that induce suppressiveness to $\mathrm{Fu}$ sarium wilt (30), and wheat cultivars that induce suppressiveness in orchard soils to apple replant disease (38). Mazzola et al. (37) showed that the wheat cv. Lewjain selected a greater proportion of phlD ${ }^{+}$pseudomonads compared with other cultivars tested. The first report of the differential response of pea cultivars to inoculation with Pseudomonas fluorescens strains was published by Åström and Gerhardson (2). They found that an increase in shoot dry weight by inoculated bacterial isolates varied with the pea cultivar. On the other hand, population sizes of a Burkholderia cepacia strain developing on roots of four pea cultivars did not differ (25).

In our work, the effect of the host crop cultivar on the selection of indigenous phlD fluorescent Pseudomonas strains was studied with four pea cultivars. There was considerable variability among the cultivars, with Little Marvel supporting the highest and Quincy the lowest populations of 2,4-DAPG producers. In the first and second cycles, differences in population sizes between these two cultivars were $\approx 1,000$ - and 10 -fold, respectively (Fig. $5)$. The effect of the pea cultivar on root colonization then was assessed by comparing the population dynamics of introduced strains Q8r1-96 (genotype D) and MVP1-4 (genotype P) on eight cultivars. Both strains aggressively colonized the rhizosphere of all eight pea cultivars; however, some interesting differences emerged. For example, although both strains are excellent colonists of pea, the population density of MVP1-4 did not differ significantly across the eight pea cultivars; however, densities of Q8r1-96 showed considerable differences in all cycles (Fig. 6). MVP1-4 originally was isolated from pea roots from the continuous pea field in Mount Vernon, WA (28), pointing to a possible better adaptation of this strain to multiple pea cultivars. During more than 30 years of pea monoculture, the field served as a breeding nursery, and literally hundreds of cultivars or lines were grown in the field. In contrast, strain Q8r1-96 was isolated from wheat grown in TAD soil that had undergone wheat monoculture. Our previous studies $(27,28,49)$ clearly indicate that the BOXPCR genotype of a strain is highly predictive of its rhizosphere competence on a given crop. However, our current results suggest that long-term contact of a specific microbial population with a crop may further "refine" its ability to colonize and interact with that crop.

In conclusion, our results showed an important effect of the host crop genotype as a modulator of rhizosphere colonization and competitiveness of 2,4-DAPG-producing $P$. fluorescens strains. To our knowledge, this is the first report indicating that plant species have a pronounced effect on the outcome of the competition among rhizobacteria belonging to the same subspecies and sharing a similar biocontrol trait.

\section{ACKNOWLEDGMENTS}

This project was supported by National Research Initiative Competitive Grant 2003-35107-13777 from the United States Department of Agriculture (USDA) Cooperative State Research, Education, and Extension Service. L. De La Fuente was partially supported by a grant received from the Storkan-Hanes-McCaslin Research Foundation. B. B. Landa is a contract holder of the 'Ramón y Cajal' programme of the Ministerio de Educación y Ciencia of Spain. We thank E. C. Sachs, S. BlouinBankhead, A. Lutes, R. Allende-Molar, A. Park, and M. Y. Son for their help with the greenhouse experiments; C. Coyne (USDA-Agricultural Research Service West Regional Plant Introduction Station, Washington State University, Pullman) for providing seed of different plant species used in this study; and L. Thomashow and D. Mavrodi for helpful discussions.

\section{LITERATURE CITED}

1. Achkar, J., Xian, M., Zhao, H., and Frost, J. W. 2005. Biosynthesis of phloroglucinol. J. Am. Chem. Soc. 127:5332-5333.

2. Åström, B., and Gerhardson, B. 1988. Differential reactions of wheat and pea genotypes to root inoculation with growth-affecting rhizosphere bacteria. Plant Soil 109:263-269.

3. Azad, H. R., Davis, J., Schnathorst, W. C., and Kado, C. I. 1985. Relationships between rhizoplane and rhizosphere bacteria and Verticillium wilt resistance in potato. Arch. Microbiol. 140:347-351.

4. Bangera, M. G., and Thomashow, L. S. 1999. Identification and characterization of a gene cluster for synthesis of the polyketide antibiotic 2,4-diacetylphloroglucinol from Pseudomonas fluorescens Q2-87. J. Bacteriol. 181:3155-3163.

5. Bergsma-Vlami, M., Prins, M. E., and Raaijmakers, J. M. 2005. Influence of plant species on population dynamics, genotypic diversity and antibiotic production in the rhizosphere by indigenous Pseudomonas spp. FEMS Microbiol. Ecol. 52:59-69.

6. Bull, C. T., Weller, D. M., and Thomashow, L. S. 1991. Relationship between root colonization and suppression of Gaeumannomyces graminis var. tritici by Pseudomonas fluorescens strain 2-79. Phytopathology 81:954-959.

7. Caetano-Anolles, G., and Gresshoff, P. M. 1991. Plant genetic control of nodulation. Annu. Rev. Microbiol. 45:345-382. 
8. Campbell, C. L., and Madden, L. V. 1990. Introduction to Plant Disease Epidemiology. John Wiley \& Sons, New York.

9. Chin-A-Woeng, T. F. C., Blomberg, G. V., Mulders, I. H. M., Dekkers, L. C., and Lugtenberg, B. J. J. 1997. Root colonization by phenazine-1carboxamide-producing bacterium Pseudomonas chlororaphis PCL1391 is essential for biocontrol of tomato foot and root rot. Mol. Plant-Microbe Interact. 13:1340-1345.

10. Cronin, D., Moënne-Loccoz, Y., Fenton, A., Dunne, C., Dowling, D. N., and O'Gara, F. 1997. Role of 2,4-diacetylphloroglucinol in the interaction of the biocontrol pseudomonad strain F113 with the potato cyst nematode Globodera rostochiensis. Appl. Environ. Microbiol. 63:1357-1361.

11. Cronin, D., Moënne-Loccoz, Y., Fenton, A., Dunne, C., Dowling, D. N., and O'Gara, F. 1997. Ecological interaction of a biocontrol Pseudomonas fluorescens strain producing 2,4-diacetylphloroglucinol with the soft rot potato pathogen Erwinia carotovora subsp. atroseptica. FEMS Microbiol. Ecol. 23:95-106.

12. De La Fuente, L., Mavrodi, D. V., Landa, B. B., Thomashow, L. S., and Weller, D. M. phlD-based genetic diversity and detection of genotypes of 2,4-diacetylpholorogucinol-producing Pseudomonas fluorescens. FEMS Microbiol. Ecol. 56:64-78.

13. De La Fuente, L., Thomashow, L. S., Weller, D. M., Bajsa, N., Quagliotto, L., Chernin, L., and Arias, A. 2004. Pseudomonas fluorescens UP61 isolated from birdsfoot trefoil rhizosphere produces multiple antibiotics and exerts a broad spectrum of biocontrol activity. Eur. J. Plant Pathol. 110:671-681.

14. de Souza, J. T., Arnould, C., Deulvot, C., Lemanceau, P., GianinazziPearson, V., and Raaijmakers, J. M. 2003. Effect of 2,4-diacetylphloroglucinol on Pythium: Cellular responses and variation in sensitivity among propagules and species. Phytopathology 93:966-975.

15. de Souza, J. T., Weller, D. M., and Raaijmakers, J. M. 2003. Frequency, diversity, and activity of 2,4-diacetylphloroglucinol-producing fluorescent Pseudomonas spp. in Dutch take-all decline soils. Phytopathology 93:5463.

16. Fravel, D. R. 2005. Commercialization and implementation of biocontrol. Annu. Rev. Phytopathol. 43:309-335.

17. Garbeya, P., van Veen, J. A., and van Elsas, J. D. 2004. Microbial diversity in soil: selection of microbial populations by plant and soil type and implications for disease suppressiveness. Annu. Rev. Phytopathol. 42:243270.

18. Haas, D., and Défago, G. 2005. Biological control of soil-borne pathogens by fluorescent pseudomonads. Nat. Rev. Microbiol. 3:307-319.

19. Hornby, D. 1979. Take-all decline: a theorist's paradise. Pages 133-158 in: Soil-borne Plant Pathogens. B. Schippers and W. Gams, eds. Academic Press, London.

20. Howell, C. R., and Stipanovic, R. D. 1979. Control of Rhizoctonia solani on cotton seedlings with Pseudomonas fluorescens and with an antibiotic produced by the bacterium. Phytopathology 69:480-482.

21. Iavicoli, A., Boutet, E., Buchala, A., and Métraux, J. P. 2003. Induced systemic resistance in Arabidopsis thaliana in response to root inoculation with Pseudomonas fluorescens CHA0. Mol. Plant-Microbe Interact. 16:851-858.

22. Isnansetyo, A., Cui, L., Hiramatsu, K., and Kamei, Y. 2003. Antibacterial activity of 2,4-diacetylphloroglucinol produced by Pseudomonas sp. AMSN isolated from a marine alga, against vancomycin-resistant Staphylococcus aureus. Int. J. Antimicrob. Agents 22:545-547.

23. Keel, C., Schnider, U., Maurhofer, M., Voisard, C., Burger, D., Haas, D., and Défago G. 1992. Suppression of root diseases by Pseudomonas fluorescens CHA0: Importance of the bacterial secondary metabolite 2,4-diacetylphloroglucinol. Mol. Plant-Microbe Interact. 5:4-13.

24. Keel, C., Weller, D. M., Natsch, A., Défago, G., Cook, R. J., and Thomashow, L. S. 1996. Conservation of the 2,4-diacetylphloroglucinol biosynthesis locus among fluorescent Pseudomonas strains from diverse geographic locations. Appl. Environ. Microbiol. 62:552-563.

25. King, E. B., and Parke, J. L. 1996. Population density of the biocontrol agent Burkholderia cepacia AMMDR1 on four pea cultivars. Soil Biol. Biochem. 28:307-312.

26. King, E. O., Ward, M. K., and Raney, D. E. 1954. Two simple media for the demonstration of pyocyanin and fluorescein. J. Lab. Clin. Med. 44:301-307.

27. Landa, B. B., Mavrodi, D. M., Thomashow, L. S., and Weller, D. M. 2003. Interactions between strains of 2,4-diacetylphloroglucinol-producing Pseudomonas fluorescens in the rhizosphere of wheat. Phytopathology 93:982-994.

28. Landa, B. B., Mavrodi, O. V., Raaijmakers, J. M., McSpadden Gardener, B. B., Thomashow, L. S., and Weller, D. M. 2002. Differential ability of genotypes of 2,4-diacetylphloroglucinol-producing Pseudomonas fluorescens strains to colonize the roots of pea plants. Appl. Environ. Microbiol. 68:3226-3237.

29. Landa, B. B., Mavrodi, O. V., Schroeder, K. L., Allende-Molar, R., and Weller, D. M. Enrichment and genotypic diversity of phlD-containing fluorescent Pseudomonas spp. in two soils after a century of wheat and flax monoculture. FEMS Microbiol. Ecol. 55:351-368.

30. Larkin, R. P., Hopkins, D. L., and Martin, F. N. 1993. Effect of successive watermelon plantings on Fusarium oxysporum and other microorganisms in soils suppressive and conducive to Fusarium wilt of watermelon. Phytopathology 83:1097-1105.

31. Lee, E.-T., and Kim, S.-D. 2001. An antifungal substance, 2,4-diacetylphloroglucinol, produced from antagonistic bacterium Pseudomonas fluorescens 2112 against Phytophthora capsici. Kor. J. Appl. Microbiol. Biotechnol. 29:37-42.

32. Lemanceau, P., Corberand, T., Gardan, L., Latour, X., Laguerre, G., Boeufgras, J., and Alabouvette, C. 1995. Effect of two plant species, flax (Linum usitatissimum L.) and tomato (Lycopersicon esculentum Mill.), on the diversity of soilborne populations of fluorescent pseudomonads. Appl. Environ. Microbiol. 61:1004-1012.

33. Mahato, S. B., Ganguly, A. N., and Sahu, N. P. 1982. Steroid saponins. Phytochemistry 21:959-978.

34. Marschner, P., Crowley, D., and Yang, C. H. 2004. Development of specific rhizosphere bacterial communities in relation to plant species, nutrition and soil type. Plant Soil 261:199-208.

35. Maurhoffer, M., Keel, C., Haas, D., and Défago, G. 1995. Influence of plant species on disease suppression by Pseudomonas fluorescens strain CHA0 with enhanced antibiotic production. Plant Pathol. 44:40-50.

36. Mavrodi, O. V., McSpadden Gardener, B. B., Mavrodi, D. V., Bonsall, R. F., Weller, D. M., and Thomashow, L. S. 2001. Genetic diversity of phlD from 2,4-diacetylphloroglucinol-producing fluorescent Pseudomonas spp. Phytopathology 91:35-43.

37. Mazzola, M., Funnell, D. L., and Raaijmakers, J. M. 2004. Wheat cultivar-specific selection of 2,4-diacetylphloroglucinol-producing fluorescent Pseudomonas species from resident soil populations. Microb. Ecol. 48:338-348.

38. Mazzola, M., and Gu, Y.-H. 2000. Impact of wheat cultivation on microbial communities from replant soils and apple growth in greenhouse trials. Phytopathology 90:114-119.

39. McSpadden Gardener, B. B., Gutierrez, L. J., Raghavendra, J., Edema, R., and Lutton, E. 2005. Distribution and biocontrol potential of phlD pseudomonads in corn and soybean fields. Phytopathology 95:715-724.

40. McSpadden Gardener, B. B., Mavrodi, D. V., Thomashow, L. S., and Weller, D. M. 2001. A rapid polymerase chain reaction-based assay characterizing rhizosphere populations of 2,4-diacetylphloroglucinolproducing bacteria. Phytopathology 91:44-54.

41. McSpadden Gardener, B. B., Schroeder, K. L., Kalloger, S. E., Raaijmakers, J. M., Thomashow, L. S., and Weller, D. M. 2000. Genotypic and phenotypic diversity of phlD-containing Pseudomonas strains isolated from the rhizosphere of wheat. Appl. Environ. Microbiol. 66:1939-1946

42. Miller, H. J., Henken, G., and van Veen, J. A. 1989. Variation and composition of bacterial populations in the rhizosphere of maize, wheat, and grass cultivars. Can. J. Microbiol. 35:656-660.

43. Murphy, J. F., Zehnder, G. W., Schuster, D. J., Sikora, E. J., Polston, J. E., and Kloepper, J. W. 2000. Plant growth-promoting rhizobacterial mediated protection in tomato against tomato mottle virus. Plant Dis. 84:779-784.

44. Okubara, P. A., Kornoely, J. P., and Landa, B. B. 2004. Rhizosphere colonization of hexaploid wheat by Pseudomonas fluorescens Q8r1-96 and Q2-87 is cultivar-variable and associated with changes in gross root morphology. Biol. Control 30:392-403.

45. Picard, C, and Bosco, M. 2003. Genetic diversity of phlD gene from 2,4diacetylphloroglucinol-producing Pseudomonas spp. strains from the maize rhizosphere. FEMS Microbiol. Lett. 219:167-172.

46. Raaijmakers, J. M., Leeman, M., van Oorschot, M. M. P., van der Sluis, I., Schippers, B., and Bakker, P. A. H. M. 1995. Dose-response relationships in biological control of Fusarium wilt of radish by Pseudomonas spp. Phytopathology 85:1075-1081.

47. Raaijmakers, J. M., Vlami, M., and de Souza, J. T. 2002. Antibiotic production by bacterial biocontrol agents. Antonie Leeuwenhoek 81:537547.

48. Raaijmakers, J. M., and Weller, D. M. 1998. Natural plant protection by 2,4-diacetylphloroglucinol- producing Pseudomonas spp. in take-all decline soils. Mol. Plant-Microbe Interact. 11:144-152.

49. Raaijmakers, J. M., and Weller, D. M. 2001. Exploiting genotypic diversity of 2,4-diacetylphloroglucinol-producing Pseudomonas spp.: characterization of superior root-colonizing P. fluorescens strain Q8r1-96. Appl. Environ. Microbiol. 67:2545-2554.

50. Ramette, A., Moënne-Loccoz, Y., and Défago, G. 2001. Polymorphism of the polyketide synthase gene phlD in biocontrol fluorescent pseudomonads producing 2,4-diacetylphloroglucinol and comparison of PhlD with plant polyketide synthases. Mol. Plant-Microbe Interact. 14:639-652.

51. Shanahan, P., O'Sullivan, D. J., Simpson, P., Glennon, J. D., and O'Gara, F. 1992. Isolation of 2,4-diacetylphloroglucinol from a fluorescent 
pseudomonad and investigation of physiological parameters influencing its production. Appl. Environ. Microbiol. 58:353-358.

52. Siddiqui, M. A, and Shaukat, S. S. 2002. Mixtures of plant disease suppressive bacteria enhance biological control of multiple tomato pathogens. Biol. Fert. Soils 36:260-268.

53. Smith, K. P., and Goodman, R. M. 1999. Host variation for interactions with beneficial plant-associated microbes. Annu. Rev. Phytopathol. 37:473-491.

54. Smith, K. P., Handelsman, J., and Goodman, R. M. 1999. Genetic basis in plants for interactions with disease-suppressive bacteria. Proc. Natl. Acad. Sci. USA 96:4786-4790.

55. Spaink, H. P. 2000. Root nodulation and infection factors produced by rhizobial bacteria. Annu. Rev. Microbiol. 54:257-288.

56. Validov, S., Mavrodi, O. V., De La Fuente, L., Boronin, A., Weller, D. M., Thomashow, L. S., and Mavrodi, D. V. 2005. Antagonistic activity among 2,4-diacetylphloroglucinol-producing fluorescent Pseudomonas spp. FEMS Microbiol. Lett. 242:249-356.

57. Vincent, M. N., Harrison, L. A., Brackin, J. M., Kovacevich, P. A.,
Mukerji, P., Weller, D. M., and Pierson, E. A. 1991. Genetic analysis of the antifungal activity of a soilborne Pseudomonas aureofaciens strain. Appl. Environ. Microbiol. 57:2928-2934.

58. Weller, D. M. 1988. Biological control of soilborne plant pathogens in the rhizosphere with bacteria. Annu. Rev. Phytopathol. 26:379-407.

59. Weller, D. M., Raaijmakers, J. M., McSpadden Gardener, B. B., and Thomashow, L. S. 2002. Microbial populations responsible for specific soil suppressiveness to plant pathogens. Annu. Rev. Phytopathol. 40:309348.

60. Weller, D. M., van Pelt, J. A., Mavrodi, D. V., Pieterse, C. M. J., Bakker, P. A. H. M., and van Loon, L. C. 2004. Induced systemic resistance (ISR) in Arabidopsis against Pseudomonas syringae pv. tomato by 2,4diacetylphloroglucinol (DAPG)-producing Pseudomonas fluorescens. (Abstr.) Phytopathology 94(suppl.):S108.

61. Wieland, G., Neumann, R., and Backhaus, H. 2001. Variation of microbial communities in soil, rhizosphere and rhizoplane in response to crop species, soil type and crop development. Appl. Environ. Microbiol. 67:5849-5854. 